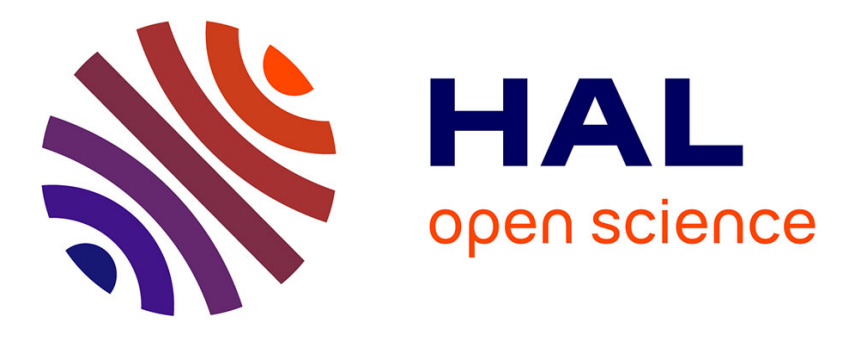

\title{
Noninvasive genetic studies of brown bears using power poles
}

\author{
Alexandros A. Karamanlidis, Elena Drosopoulou, Miguel Gabriel Hernando, \\ Lazaros Georgiadis, Lambros Krambokoukis, Stavri Pllaha, Andreas \\ Zedrosser, Zacharias Scouras
}

\section{To cite this version:}

Alexandros A. Karamanlidis, Elena Drosopoulou, Miguel Gabriel Hernando, Lazaros Georgiadis, Lambros Krambokoukis, et al.. Noninvasive genetic studies of brown bears using power poles. European Journal of Wildlife Research, 2010, 56 (5), pp.693-702. 10.1007/s10344-010-0363-3 . hal-00568367

\section{HAL Id: hal-00568367 https://hal.science/hal-00568367}

Submitted on 23 Feb 2011

HAL is a multi-disciplinary open access archive for the deposit and dissemination of scientific research documents, whether they are published or not. The documents may come from teaching and research institutions in France or abroad, or from public or private research centers.
L'archive ouverte pluridisciplinaire HAL, est destinée au dépôt et à la diffusion de documents scientifiques de niveau recherche, publiés ou non, émanant des établissements d'enseignement et de recherche français ou étrangers, des laboratoires publics ou privés. 


\title{
Noninvasive genetic studies of brown bears using power poles
}

\author{
Alexandros A. Karamanlidis • Elena Drosopoulou • Miguel de Gabriel Hernando • \\ Lazaros Georgiadis • Lambros Krambokoukis • Stavri Pllaha • Andreas Zedrosser • \\ Zacharias Scouras
}

Received: 27 August 2009 /Revised: 13 December 2009/Accepted: 13 January 2010 /Published online: 23 February 2010

(C) Springer-Verlag 2010

\begin{abstract}
One difficulty in the conservation of endangered wildlife is the lack of reliable information on its status. This lack of knowledge can often be attributed to financial and logistic constraints as well as the lack of trained personnel to collect data. We test a simple method to study bears in the southern Balkans by inspecting power poles, which are used by bears for marking and rubbing purposes. We created a network of barbed-wire fitted poles for the collection of hair
\end{abstract}

Communicated by H. Kierdorf

A. A. Karamanlidis $(\bowtie) \cdot$ M. de Gabriel Hernando •

L. Georgiadis $\cdot$ L. Krambokoukis

ARCTUROS, Civil Society for the Protection

and Management of Wildlife and the Natural Environment,

Roggoti Str. 3,

54624 Thessaloniki, Greece

e-mail: akaramanlidis@gmail.com

E. Drosopoulou $\cdot$ Z. Scouras

Department of Genetics, Development and Molecular Biology,

School of Biology, Faculty of Sciences,

Aristotle University of Thessaloniki,

54124 Thessaloniki, Greece

S. Pllaha

Transborder Wildlife Association,

Rr. Pandeli Cale Nr. 26,

Korçë, Albania

\section{A. A. Karamanlidis $\cdot$ A. Zedrosser}

Department of Ecology and Natural Resource Management, Norwegian University of Life Sciences,

P.O. Box 5003, 1432 Ås, Norway

\section{A. Zedrosser}

Department of Integrative Biology and Biodiversity Research, Institute of Wildlife Biology and Game Management,

University of Natural Resources and Applied Life Sciences,

Gregor-Mendel Str. 33,

1180 Vienna, Austria samples, evenly distributed throughout six study areas. During 87 sampling sessions in the main study area, we collected 191 samples and identified six microsatellite loci that were variable enough for individual bear identification. The most and best-quality hair samples were collected during the mating period, and DNA was most successfully extracted from samples remaining $<4$ weeks in the field. In the six study areas, we identified 47 bears. An advantage of using power poles for hair sampling is their availability and accessibility; no bait is required, and the network can be easily set up. A drawback may be an unequal capture probability of sex and age classes of bears. Despite this limitation, using power poles proved to be a simple and cheap method for the noninvasive genetic study of bears that did not require any prior knowledge on habitat use and activity patterns. The method is suitable for large-scale surveys to estimate distribution and relative densities of bears and could also be applied for studying other species.

Keywords Conservation · DNA · Endangered species . Greece · Management · Methodology · Southern Balkans · Ursus arctos

\section{Introduction}

Several species of terrestrial mammals are critically endangered, and some will perish unless effective conservation measures are implemented soon (Ceballos and Ehrlich 2002; Schipper et al. 2008). Large carnivores are often species of particular conservation concerns (Boitani 2000; Breitenmoser et al. 2000; Swenson and Sandegren 2000). Despite costly recovery efforts, our general knowledge over the status and biology of many large carnivores still remains incomplete (Karanth and Chellam 2009), and 
wildlife ecologists and conservation biologists are constantly in search of new methods to monitor and protect them more efficiently (Long et al. 2008).

Noninvasive genetic monitoring has emerged as a sensitive, reliable, and time- and cost-efficient tool to deal with the inherent difficulties of studying rare, elusive, and often endangered animals (Schwartz et al. 2006). Traps for collecting hairs for subsequent genetic analysis have been successfully used across a wide range of species and geographical locations (Belant 2003; Long et al. 2007; Castro-Arellano et al. 2008). To increase the reliability of methods and results of genetic studies, Waits and Paetkau (2005) recommended carrying out pilot studies prior to initiating a new study in order to determine the optimal study method.

The brown bear (Ursus arctos) is the most widespread bear species in the world, with a Holarctic distribution in Europe, Asia, and North America (Servheen et al. 1999). In Europe, human persecution and habitat loss have led to the disappearance of the species from large parts of its original range (Zedrosser et al. 2001). Bear populations in the southern Balkans, i.e., in Albania, the Former Yugoslav Republic of Macedonia (FYROM), and Greece, are considered to be particularly endangered, not only because of their small sizes but also due to the lack of systematic and coordinated efforts to study and protect them (Zedrosser et al. 2001). Considering the socioeconomic changes currently taking place throughout the region and their potential effects on habitat connectivity (Karamanlidis and Mertzanis 2003; Karamanlidis and Georgiadis 2009), there is an urgent need for a method to rapidly and reliably obtain data on the status and distribution of the species.

Marking and rubbing behavior of brown bears on poles of the electricity and telephone network (hereafter referred to as power poles) was recorded in Greece in 2003, and a method was developed to document the presence of the species in the country. As a result of the marking and rubbing behavior of the species, bear hair was commonly found on power poles (Karamanlidis et al. 2007). We have used the hair left from this behavior to study brown bears with a noninvasive genetic method. The specific aims of our study were to:

1. Design a protocol for the systematic noninvasive genetic study of brown bears using hairs found on power poles.

2. Test the protocol on a large geographic scale in the southern Balkans.

\section{Materials and methods}

Pilot study area

The protocol for our systematic noninvasive genetic study of brown bears was developed and initially tested in a pilot study area of $630 \mathrm{~km}^{2}$ in the Prefecture of Grevena, in the central part of the Pindos Mountain Range in northwestern Greece (Fig. 1). Major forest vegetation types consisted of oak (Quercus sp.) and black pine (Pinus nigra). The area was characterized by a mosaic of dense forests, openings, and small-scale agricultural cultivations. Elevations ranged between 500 and 2,200 $\mathrm{m}$, and human activity was intense at lower elevations. This pilot study area was located at the center of the species' western nucleus of distribution in Greece (Mertzanis 1994) and is the construction site of two major highways (Karamanlidis and Mertzanis 2003; Karamanlidis and Georgiadis 2009).

Study area in the southern Balkans for the large-scale testing of the method

We tested the protocol on a wider geographical scale in areas of known and expected bear distribution within Greece, Albania, and FYROM (Mertzanis 1994; Zedrosser et al. 2001; Karamanlidis et al. 2007; Fig. 1). In addition to resampling our pilot study area, we selected areas at the prefectures of Florina and Trikala and at Mount Grammos, within the western nucleus of the distribution of the species in the country (Mertzanis 1994; Fig. 1). The study area in Florina was located north of the pilot study area, was $1,017 \mathrm{~km}^{2}$ large, and was densely populated by humans. Mount Grammos is a sparsely populated, high mountain massif northwest of the pilot study area; the study site there was $740 \mathrm{~km}^{2}$. The study site in Trikala was $708 \mathrm{~km}^{2}$ and was separated from the pilot study area by an interstate road.

Study areas in Albania $\left(496 \mathrm{~km}^{2}\right)$ and FYROM $\left(5,615 \mathrm{~km}^{2}\right)$ were selected in the southern parts of both countries adjacent to the borders with Greece (i.e., the study areas in both countries constituted an extension of the study areas at Mount Grammos and the prefecture of Florina, and the habitat was very similar), in order to collect information that could eventually be used in the transborder management and protection of the species (Fig. 1).

Sampling procedures of the pilot study

Power poles are made of wood (approximately $30-50 \mathrm{~cm}$ in diameter and $10 \mathrm{~m}$ high) and processed with a wood preservative (i.e., coal tar creosote, a substance derived from tars) to resist decay and insect damage. Depending on topography, poles are usually placed 50 to $100 \mathrm{~m}$ apart, and vegetation is cleared $5 \mathrm{~m}$ from each side of the power pole line. At the beginning of our pilot study, we inspected all 841 power poles present in the pilot study area and classified them according to the intensity of their use (i.e., how intensively they were used for marking or/and rubbing by bears) by applying the classification system developed by Karamanlidis (2008; Table 1). Power poles $(N=39)$ 
Fig. 1 Map of the southern Balkans indicating the locations of the six study areas in Albania, the Former Yugoslav Republic of Macedonia (FYROM), and Greece (Florina, Grammos, Grevena, Trikala), the power poles inspected, and the poles that were used as sampling stations for genetic sampling

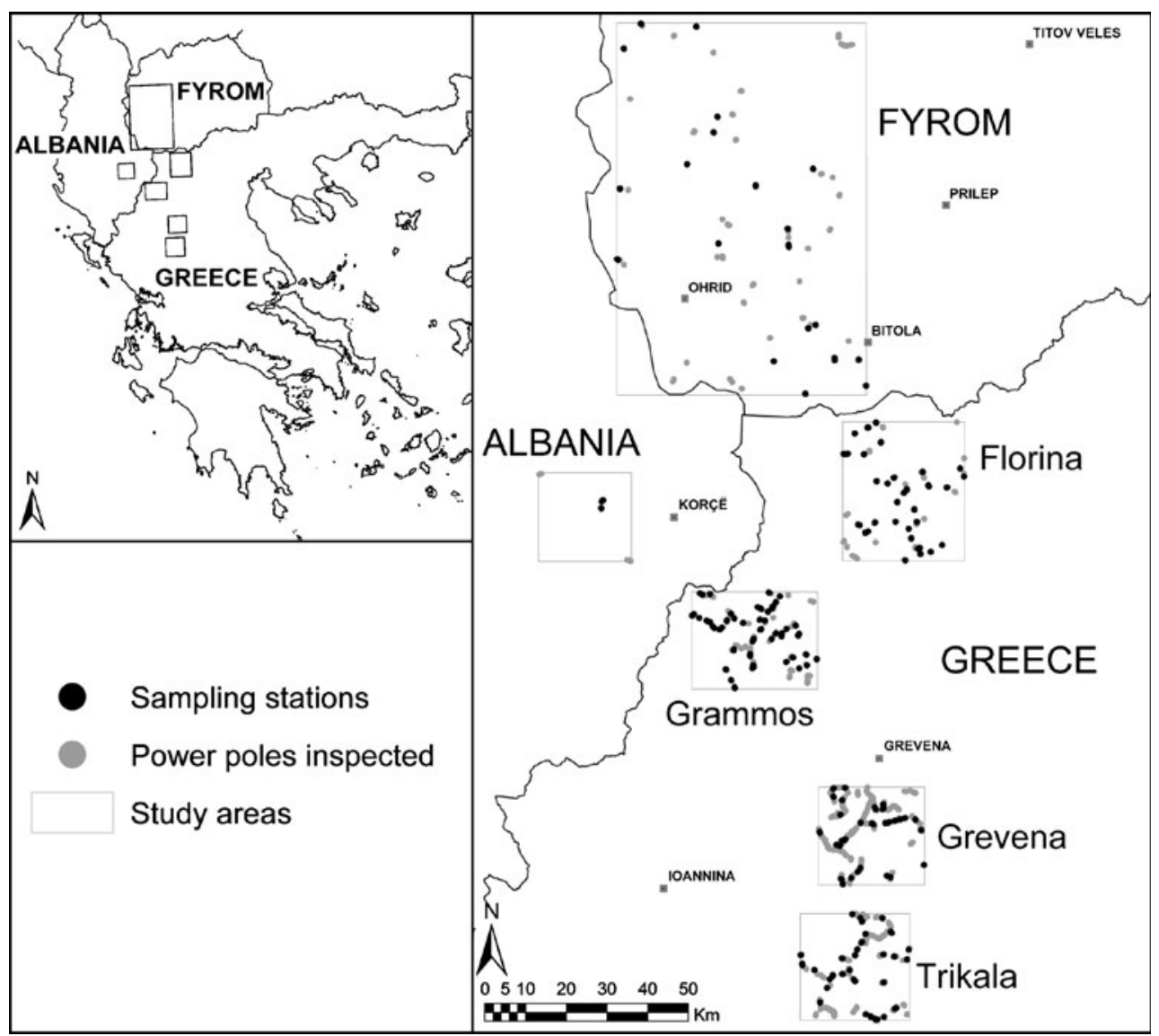

evenly distributed across the study area were selected for the creation of a noninvasive, genetic sampling network, and whenever possible we used poles with a high intensity of use. Each power pole/sampling station was fitted with barbed wire (Kendall and McKelvey 2008). All hairs found on one barb of the barbed wire on a given power pole were considered as one sample; all samples were macroscopically examined and classified according to their quality, i.e.,

Table 1 Number of power poles used in six networks for genetic sampling and their intensity of use by brown bears (I: low rubbing activity; II: low marking activity; III: medium marking and rubbing activity; IV: the number of existing guard hairs (sample category 0: no guard hairs in the sample, I: one to five guard hairs in the sample, II: six to ten guard hairs in the sample, III: more than ten guard hairs in the sample). We defined also three periods for data collection; period A: hibernation (JanuaryApril); period B: mating (May-August); period C: hyperphagia (September-December). These broad sampling periods were defined considering the general activity and

\begin{tabular}{|c|c|c|c|c|c|c|c|c|c|c|c|}
\hline \multirow[t]{2}{*}{ Study area } & \multicolumn{2}{|l|}{ I } & \multicolumn{2}{|l|}{ II } & \multicolumn{2}{|l|}{ III } & \multicolumn{2}{|l|}{ IV } & \multicolumn{2}{|l|}{$\mathrm{V}$} & \multirow[t]{2}{*}{ Nr. poles/area } \\
\hline & $N$ & $N / 100 \mathrm{~km}^{2}$ & $N$ & $N / 100 \mathrm{~km}^{2}$ & $N$ & $N / 100 \mathrm{~km}^{2}$ & $N$ & $N / 100 \mathrm{~km}^{2}$ & $N$ & $N / 100 \mathrm{~km}^{2}$ & \\
\hline Albania & 0 & 0 & 2 & 0.4 & 0 & 0 & 2 & 0.4 & 2 & 0.4 & 6 \\
\hline FYROM & 3 & 0.05 & 3 & 0.05 & 18 & 0.3 & 1 & 0.01 & 8 & 0.1 & 33 \\
\hline Greece/Florina & 5 & 0.5 & 8 & 1.4 & 25 & 2.4 & 2 & 0.2 & 12 & 1.1 & 52 \\
\hline Greece/Grammos & 1 & 0.1 & 3 & 0.4 & 20 & 2.7 & 2 & 0.2 & 46 & 6.2 & 72 \\
\hline Greece/Grevena & 0 & 0 & 2 & 0.3 & 19 & 3.0 & 3 & 0.4 & 30 & 4.7 & 54 \\
\hline Greece/Trikala & 3 & 0.4 & 10 & 1.4 & 28 & 3.9 & 3 & 0.4 & 11 & 1.5 & 55 \\
\hline Overall no. of poles & 12 & & 28 & & 110 & & 13 & & 109 & & 272 \\
\hline
\end{tabular}

$N / 100 \mathrm{~km}^{2}$ is a density index of the sampling network, calculated as the number of sampling power poles divided by the size of the study area in $100 \mathrm{~km}^{2}$ 
habitat use patterns of brown bears in these latitudes (Huber and Roth 1992; Mertzanis et al. 2005, 2008; Fernandez-Gil et al. 2006), taking into account specific environmental conditions in Greece. During mild winters, some bears in the country appear to be active and have been recorded to mark and rub on power poles throughout the winter (Karamanlidis 2008). We determined the best time period for sample collection by comparing the total number of samples collected and the quality of samples of each power pole sampling session in each period. We estimated the density of the sampling network by dividing the number of power pole sampling stations by the size of a study area.

All samples collected from each power pole per month belonged to the same power pole sampling session. Genetic analysis of a power pole sampling session started with category III samples and ended with these samples if they provided enough DNA for genetic analysis. If not, we continued with the analysis of category II samples until we either were able to extract DNA or we ran out of samples. The quality of each power pole sampling session was characterized by the category of the sample that provided enough DNA for genetic analysis. To monitor the effect of field conditions on the amount and quality of DNA extracted and to determine the best frequency for the inspection of power poles and collecting samples, we collected hair samples on a monthly basis in periods A and B (intensive sampling period) and once in period $\mathrm{C}$ (nonintensive sampling period) and compared the percentage of power pole sampling sessions that had samples from which DNA could be extracted between the two sampling periods.

\section{Individual and sex identification of brown bears}

Hair samples were placed in paper envelopes without contacting human skin and then stored at room temperature in ziplock bags with silica gel (Roon et al. 2003). For every collected hair sample, DNA extractions were performed using the DNeasy Blood and Tissue kits (QIAGEN, Hilden, Germany) following the manufacturer's instructions. We aimed at using ten guard hairs where available. All extractions took place in a building in which amplified DNA had never been handled.

To identify the loci that could be used for identification of individuals, we used 49 samples collected in the pilot study area, which we screened at the markers $G 1 D, G 10 C$, G10P (Paetkau et al. 1995), G10J (Paetkau et al. 1998), and MU05 and MU59 (Taberlet et al. 1997). Sex identification was established through the analysis of the amelogenin gene (Ennis and Gallagher 1994).

Thermal cycling was performed using an MJ Research PTC100 thermocycler with 96-well "gold" blocks. Polymerase chain reaction (PCR) buffers and conditions were according to Paetkau et al. (1998), except that markers were not coamplified, as coamplification reduced success rates for hair samples (Paetkau, personal communication). We used 3 $\mu 1$ of DNA extract per PCR reaction, except during error checking, when $5 \mu 1$ was used; this way, bad samples were culled efficiently, and we did not run out of DNA at samples that needed a lot of cleanup. $\left[\mathrm{MgCl}_{2}\right]$ was $2.0 \mathrm{mM}$ for all markers except G10J (1.8 mM). Microsatellite analysis used ABI's four-color detection system; we used an automated sequencer (ABI 310), and genotypes were determined using ABI Genescan and Genotyper software. Error checking and general quality assurance followed the recommendations in Paetkau (2003) and Roon et al. (2005) and summarized by Kendall et al. (2008).

Test of a large-scale genetic study of brown bears in the southern Balkans

Based on the experience acquired in the pilot study, 2,568 power poles were inspected in the six study areas in 2007 (the pilot study area was revisited because since 2005 several power poles had been added to the local electricity network) and classified according to their use by bears (see methods of the pilot study). Based on the geographical distribution of the power poles and their use by bears, we created a sampling network of 272 power poles, which were fitted with barbed wire in March 2008, thus creating six local sampling networks (Fig. 1, Table 1).

Based on results of the pilot study for the best period for sampling and the quality of the samples obtained, the six sampling networks were inspected once monthly in April and May 2008. The genetic study of the hair samples collected followed the same guidelines and was based on the loci described for the pilot study.

\section{Results}

Results of the pilot study

We collected 191 hair samples during 87 power pole sampling sessions during the monthly inspection of the sampling network in the pilot study area (Table 2). The number of hair samples collected in the three periods differed statistically (Friedman test $X^{2} 10.425$, df 2, $P<0.05$ ); $58 \%$ of the samples were collected during the mating period (mean number of samples collected per power pole: hibernation period 1.3, mating period 2.78 , hyperphagia period 0.70 ). The quality of the sampling sessions in the three periods also differed statistically $\left(X^{2}\right.$ test of association 18.724, df 6, $\left.P<0.05\right)$. During the hibernation period, we collected more category 0 samples than expected, whereas we found more high-quality samples than expected during the mating period. Finally, DNA was successfully extracted from $78 \%$ and $82 \%$ of the 
Table 2 Number of samples collected and number and quality of sessions of 39 power pole sampling stations in the pilot study area, in the Prefecture of Grevena/Greece (January-December 2005)

\begin{tabular}{|c|c|c|c|c|c|c|}
\hline \multirow[t]{2}{*}{ Period } & \multirow[t]{2}{*}{ Samples collected } & \multirow[t]{2}{*}{ Power pole sampling session } & \multicolumn{4}{|c|}{ Power pole sampling session quality (category) } \\
\hline & & & 0 & I & II & III \\
\hline Hibernation & 52 & 24 & 6 & 5 & 9 & 4 \\
\hline Mating & 111 & 43 & 4 & 9 & 15 & 15 \\
\hline Hyperphagia & 28 & 20 & 0 & 8 & 12 & 0 \\
\hline Total & 191 & 87 & 10 & 22 & 36 & 19 \\
\hline
\end{tabular}

samples collected after remaining $<4$ weeks in the field, but only $25 \%$ of the samples collected after $>4$ weeks yielded enough DNA for subsequent use in genetic analysis.

The six loci screened were polymorphic with five to eight alleles and had a mean expected heterozygosity of $\mathrm{He}=0.76$ (Table 3). In our dataset, we found 173 mismatch pairs, which would lead to an approximate expectation of 1.7 2 mismatch pairs, 0.171 mismatch pairs, and 0.017 pairs of individuals with identical six-locus genotypes. The observation of no 1 mismatch or 2 mismatch pairs indicates that it was unlikely that we underestimated the number of individuals by sampling any pairs of individuals with matching multilocus genotypes (Waits and Paetkau 2005). We considered therefore the loci chosen in our pilot study to be variable enough and suitable for individual identification of brown bears in the region.

Results of the large-scale genetic study of brown bears in the southern Balkans

The overall density of the six sampling networks ranged from 0.58 to 9.72 sampling stations per $100 \mathrm{~km}^{2}$. During the inspection of the sampling networks, 328 hair samples (149 in April, 179 in Mai) were collected, and 76 samples were of high enough quality (i.e., contained hair follicles) and genetically analyzed. Forty-seven unique genotypes were identified; these included four females (three in May in FYROM and one in May in Greece/Grammos) and six individuals that were recaptured (five individuals were recaptured once and one individual was recaptured twice; one individual was captured in April in Greece/Trikala and Greece/Grevena). In total, in the study areas in Albania, FYROM, Greece/Florina, Greece/Grammos, Greece/Grevena, and Greece/Trikala, we identified one, four, ten, sixteen, twelve, and four different individuals, respectively (Table 4).

\section{Discussion}

Inspection of power poles for bear hairs has been part of a recent noninvasive genetic study of brown bears in north- western Montana (Kendall et al. 2009); however, the present study is the first one to rely exclusively on the inspection of power poles to study brown bears. The installation of a network for sampling brown bear hair using power poles and its systematic inspection led to the collection of enough samples to initiate the first genetic study of the species in the southern Balkans. The six genetic markers selected enabled the identification of 47 individuals.

Noninvasive sampling has become an essential tool in assessing genetic and demographic parameters of endangered bear populations around the world (Taberlet et al. 1997; Bellemain et al. 2007; Gervasi et al. 2008; Kendall et al. 2009). Collecting hair from rare and elusive animals usually involves the setting of (baited) hair snares/traps in the field (Kendall and McKelvey 2008) or the collection of hair from rub trees; such methods require detailed information on bear habitat and activity, scientific expertise, and considerable logistic and financial resources (Kendall et al. 2008, 2009). The approach used in this study took advantage of the natural behavior of the research species and did not require the use of bait. As power poles are found at fixed, easily identifiable, and easily accessible locations that cover a large area, there is no need for extensive prior knowledge of bear behavior or habitat use. These advantages make the method ideal for use with volunteers (Sadlier et al. 2004), in cases of conservation urgency and/or logistic and financial constraints. In addition, power poles may also be used to monitor other species; wild boar (Sus scrofa) used the poles for marking and rubbing purposes, as shown by numerous hair samples collected during the course of this study. Observations carried out during a study on the marking behavior of brown bears in the pilot study area using infrared cameras (Karamanlidis, unpublished data) indicate that a modification of the approach presented in this study using bait could be used to monitor stone martens (Martes foina) and pine martens (Martes martes).

The number of hair samples collected from the power poles was highest in late spring and early summer and was directly associated with the marking and rubbing behavior of brown bears (Fig. 2). Marking and rubbing in bears are a 
Table 3 Number of alleles, allele size and frequency, and expected $(\mathrm{He})$ and observed (Ho) heterozygosities for six microsatellite loci analyzed from 49 hair samples of brown bears during a pilot study from the Prefecture of Grevena, Greece, in 2005

\begin{tabular}{|c|c|c|c|c|c|}
\hline Locus & Number of alleles & Allele size & Allele frequency & $\mathrm{He}$ & Ho \\
\hline \multirow[t]{6}{*}{ G1D } & 6 & 172 & 0.041 & \multirow[t]{6}{*}{0.76} & \multirow[t]{6}{*}{0.63} \\
\hline & & 176 & 0.153 & & \\
\hline & & 178 & 0.122 & & \\
\hline & & 180 & 0.235 & & \\
\hline & & 182 & 0.061 & & \\
\hline & & 184 & 0.388 & & \\
\hline \multirow[t]{6}{*}{ G10C } & 6 & 193 & 0.01 & \multirow[t]{6}{*}{0.80} & \multirow[t]{6}{*}{0.76} \\
\hline & & 197 & 0.122 & & \\
\hline & & 201 & 0.153 & & \\
\hline & & 203 & 0.224 & & \\
\hline & & 205 & 0.245 & & \\
\hline & & 207 & 0.245 & & \\
\hline \multirow[t]{6}{*}{ G10J } & 6 & 178 & 0.378 & \multirow[t]{6}{*}{0.68} & \multirow[t]{6}{*}{0.76} \\
\hline & & 180 & 0.194 & & \\
\hline & & 188 & 0.378 & & \\
\hline & & 190 & 0.02 & & \\
\hline & & 192 & 0.01 & & \\
\hline & & 196 & 0.02 & & \\
\hline \multirow[t]{8}{*}{ G10P } & 8 & 145 & 0.01 & \multirow[t]{8}{*}{0.80} & \multirow[t]{8}{*}{0.81} \\
\hline & & 147 & 0.26 & & \\
\hline & & 151 & 0.052 & & \\
\hline & & 153 & 0.01 & & \\
\hline & & 155 & 0.042 & & \\
\hline & & 157 & 0.146 & & \\
\hline & & 159 & 0.198 & & \\
\hline & & 163 & 0.281 & & \\
\hline \multirow[t]{5}{*}{ MU50 } & 5 & 110 & 0.041 & \multirow[t]{5}{*}{0.73} & \multirow[t]{5}{*}{0.8} \\
\hline & & 124 & 0.235 & & \\
\hline & & 126 & 0.316 & & \\
\hline & & 128 & 0.337 & & \\
\hline & & 130 & 0.071 & & \\
\hline \multirow[t]{7}{*}{ MU59 } & 7 & 219 & 0.286 & \multirow[t]{7}{*}{0.80} & \multirow[t]{7}{*}{0.88} \\
\hline & & 225 & 0.194 & & \\
\hline & & 227 & 0.255 & & \\
\hline & & 239 & 0.01 & & \\
\hline & & 241 & 0.051 & & \\
\hline & & 243 & 0.061 & & \\
\hline & & 251 & 0.143 & & \\
\hline
\end{tabular}

ubiquitous, but still poorly understood, aspect of the species' behavior (Green and Mattson 2003; Karamanlidis et al. 2007). The greater marking and rubbing activity of brown bears in our study area coincided with the mating season of the species in these latitudes (Fernandez-Gil et al. 2006) and was most probably associated with it. Similar behavior has been also suggested for grizzly bears in North America (Green and Mattson 2003) and other carnivore species (Schmidt and Kowalczyk 2006). Power poles are prominent features of the landscape at regular intervals and are, in addition, treated with creosote, a strong smelling substance used to protect the wood against rotting. These characteristics most likely make them a preferred place for marking and rubbing purposes.

Considerable effort has been invested in identifying the most suitable storage methods for the preservation of genetic material from bears that will guarantee the best DNA amplification rates (Murphy et al. 2000, 2003; Roon et al. 2003). In contrast, little is known about the effect of field conditions on DNA amplification rates. Our results indicate that the quality and amount of DNA extracted from hair samples decrease the longer the samples remain in the field, similar as with scats (Piggott 2004; Bellemain et al. 2007). Generally, the quality of hair samples was lowest 

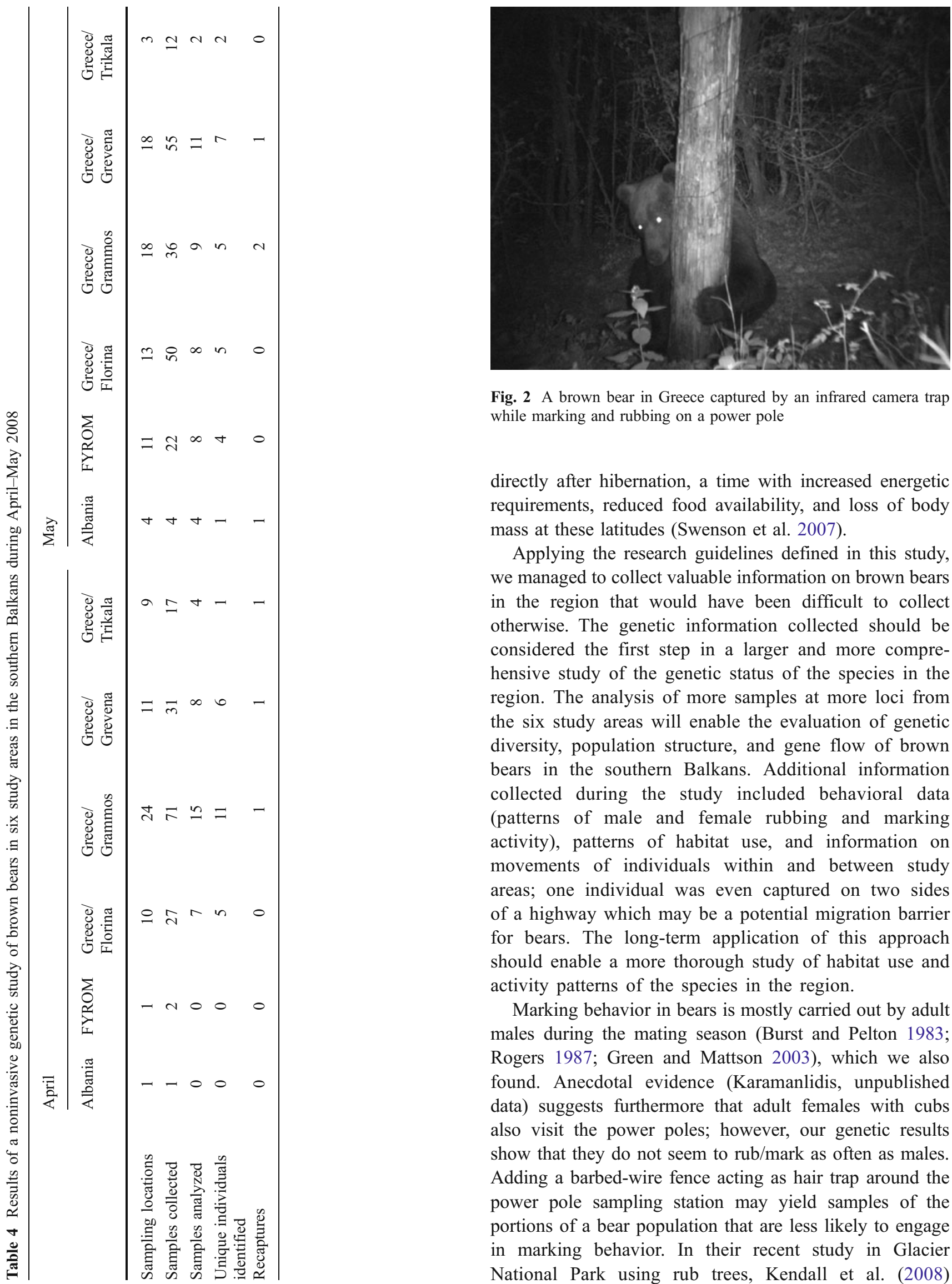

Fig. 2 A brown bear in Greece captured by an infrared camera trap while marking and rubbing on a power pole

directly after hibernation, a time with increased energetic requirements, reduced food availability, and loss of body mass at these latitudes (Swenson et al. 2007).

Applying the research guidelines defined in this study, we managed to collect valuable information on brown bears in the region that would have been difficult to collect otherwise. The genetic information collected should be considered the first step in a larger and more comprehensive study of the genetic status of the species in the region. The analysis of more samples at more loci from the six study areas will enable the evaluation of genetic diversity, population structure, and gene flow of brown bears in the southern Balkans. Additional information collected during the study included behavioral data (patterns of male and female rubbing and marking activity), patterns of habitat use, and information on movements of individuals within and between study areas; one individual was even captured on two sides of a highway which may be a potential migration barrier for bears. The long-term application of this approach should enable a more thorough study of habitat use and activity patterns of the species in the region.

Marking behavior in bears is mostly carried out by adult males during the mating season (Burst and Pelton 1983; Rogers 1987; Green and Mattson 2003), which we also found. Anecdotal evidence (Karamanlidis, unpublished data) suggests furthermore that adult females with cubs also visit the power poles; however, our genetic results show that they do not seem to rub/mark as often as males. Adding a barbed-wire fence acting as hair trap around the power pole sampling station may yield samples of the portions of a bear population that are less likely to engage in marking behavior. In their recent study in Glacier National Park using rub trees, Kendall et al. (2008) 
documented unequal capture probabilities of individual bears depending on age class, sex, and distance of bears from nearest rub tree. Therefore, if sampling of power poles is to be used as a method for demographic or capturerecapture analyses, then potential differences in capture probabilities must be considered.

Brown bear populations in Albania, FYROM, and Greece have been estimated to number less than 250 individuals in each country (Zedrosser et al. 2001); however, these estimates can merely be considered educated guesses. The sampling network established in Greece appeared to be dense enough to estimate a minimum population size, as it enabled the identification of 42 individuals over a 2-month period. In comparison, five individuals were identified in FYROM and Albania. In FYROM, the sampling network currently does not appear to be dense enough, and the location of more sampling stations is necessary in order to identify more individuals. In Albania, the method does not seem to be applicable, as wooden power poles have been replaced with concrete power poles, which are not attractive for marking and rubbing by bears.

Conservation actions for the protection of brown bears in the southern Balkans have been hampered by the lack of reliable information on the status of the species in the region. Little information is available from Greece (Vlachos et al. 2000; Mertzanis et al. 2005; Kanellopoulos et al. 2006; Karamanlidis et al. 2007), and to our knowledge no published information is available from Albania and FYROM, besides a population estimate (Zedrosser et al. 2001). The main reasons for the lack of knowledge in the southern Balkans are the logistic and financial constraints and the lack of trained personnel necessary for the collection of field data on brown bears. The use of power poles as a simple and cheap field method for the noninvasive genetic study of bears can reduce these problems and therefore be important for conservation. The inspection of power poles and the collection of hair samples in our study required one person in Albania and FYROM and two people in Greece, resulting in minimal organizational, financial, and logistic resources. We therefore believe that the use of power poles that have been treated with creosote, for the collection of hair samples, is a methodological approach suitable for especially small budgets.

We recommend that sampling should be focused on the mating season and that sampling stations should be visited at least once a month to ensure the quality of the samples for later genetic analysis. A density of $>1.1$ power poles of category V per $100 \mathrm{~km}^{2}$ was successful in Greece and can be used as a recommendation for spatial sampling intensity. The results of our study in combination with livestock and crop damage data (Hellenic Agricultural Insurance Agency, personal communication) and brown bear distribution data in Greece (Karamanlidis, unpublished data) indicate that the density of power poles in relation to the intensity they are being used by bears for rubbing and/or marking is positively correlated to the density of brown bears in a given area. Therefore, spatial sampling intensity will depend on individual bear density, and study designs in other areas might have to deal with a lower density of category $\mathrm{V}$ poles and/or a higher percentage of lowerquality power poles. A further disadvantage of our method may be that the possibilities for a random study design or an increase in the density of sampling stations is reduced by having to use fixed locations. It should be noted that our method might not be applicable any more in some countries where wooden power poles have been replaced with concrete ones or with wooden ones that have not been treated with creosote.

In Greece, the monitoring network established in this study could serve as a basis and should be expanded to the south and northeast in order to cover the entire range of the western subpopulation. In FYROM, the current network should be expanded to the north and intensified. In Albania, due to the special circumstances in the parts of the country where this study was carried out, monitoring of the species has to rely on data from multiple sources (Boulanger et al. 2008). Considering the logistic and financial constraints for bear research and conservation in the southern Balkans, an extensive network of power pole sampling stations and their regular inspection in the region are currently underway (Karamanlidis et al. 2009). The application of a common methodology throughout the southern Balkans will enable the comparison of results and provide the baseline scientific information that has been identified in the Action Plan for the Conservation of the Brown Bear in Europe as a priority action for the effective conservation of the species in the region (Swenson et al. 2000).

Acknowledgements We would like to thank the field teams of the Transborder Wildlife Association, Molika, and ARCTUROS for their assistance in the field in collecting the hair samples and the Hellenic Ministry of Rural Development and Food for providing the necessary research permits. The biggest part of the genetic analyses was carried out at the labs of Wildlife Genetics International. We thank Renee Prive and David Paetkau for their outstanding work and cooperation, Kate Kendall for guidance in setting up the project, and Jon Swenson and three anonymous reviewers for valuable comments that improved this manuscript. This project received generous financial support from Alertis, fund for bear and nature conservation, the International Association for Bear Research and Management, the NGO ARCTUROS, and Vodafone Greece. All research activities carried out in Albania, FYROM, and Greece comply with the current laws of the country in which they were performed.

\section{References}

Belant JL (2003) A hair snare for forest carnivores. Wildl Soc Bull 31:482-485 
Bellemain E, Ali Nawaz M, Valentini A, Swenson JE, Taberlet P (2007) Genetic tracking of the brown bear in northern Pakistan and implications for conservation. Biol Conserv I34:537-547

Boitani L (2000) Action plan for the conservation of wolves in Europe. Nature and environment. Council of Europe, Strasbourg, p 113

Boulanger J, Kendall KC, Stetz JB, Roon DA, Waits LP, Paetkau D (2008) Multiple data sources improve DNA-based markrecapture population estimates of grizzly bears. Ecol Appl 18:577-589

Breitenmoser U, Breitenmoser-Würsten C, Okarma H, Kaphegyi T, Kaphegyi-Wallmann U, Müller UM (2000) Action plan for the conservation of the Eurasian lynx in Europe. Nature and environment. Council of Europe, Strasbourg, p 112

Burst TL, Pelton MR (1983) Black bear mark trees in the Smoky Mountains. International Conference on Bear Research and Management 5:45-53

Castro-Arellano I, Madrid-Luna C, Lacher TEJ, León-Paniagua L (2008) Hair-trap efficacy for detecting mammalian carnivores in the tropics. J Wildl Manage 72:1405-1412

Ceballos G, Ehrlich PR (2002) Mammal population losses and the extinction crisis. Science 296:904-907

Ennis S, Gallagher T (1994) PCR based sex determination assay in cattle based on bovine Amelogenin locus. Anim Genet 25:425427

Fernandez-Gil A, Naves J, Delibes M (2006) Courtship of brown bears Ursus arctos in northern Spain: phenology, weather, habitat and durable mating areas. Wildl Biol 12:367-373

Gervasi V, Ciucci P, Boulanger J, Posillico M, Sulli C, Focardi S, Randi E, Boitani L (2008) A preliminary estimate of the Apennine brown bear population size based on hair-snag sampling and multiple data source mark-recapture Huggins models. Ursus 19:105-121

Green GI, Mattson DJ (2003) Tree rubbing by Yellowstone grizzly bears Ursus arctos. Wildl Biol 9:1-9

Huber D, Roth HU (1992) Denning of brown bears in Croatia. International Conference on Bear Research and Management 9:271-281

Kanellopoulos N, Mertzanis G, Korakis G, Panagiotopoulou M (2006) Selective habitat use by brown bear (Ursus arctos L.) in northern Pindos, Greece. J Biol Res 5:23-33

Karamanlidis AA (2008) Development of an innovative method for studying genetic, demographic and behavioural aspects of the brown bear (Ursus arctos). Ph.D. Thesis, Aristotle University of Thessaloniki

Karamanlidis AA, Georgiadis L (2009) Brown bear habitat fragmentation in Greece: monitoring effects of the construction of the "E65" highway. Int Bear News 18:16

Karamanlidis AA, Mertzanis G (2003) Paving a new way for brown bears in Greece. Int Bear News 12:8-9

Karamanlidis AA, Youlatos D, Sgardelis S, Scouras Z (2007) Using sign at power poles to document presence of bears in Greece. Ursus 18:54-61

Karamanlidis AA, Georgiadis L, Zedrosser A (2009) The "Southwestern Balkans Bear Register": a tool in the conservation of brown bears in the southwestern Balkans. Int Bear News 18:1314

Karanth KU, Chellam R (2009) Carnivore conservation at the crossroads. Oryx 43:1-2

Kendall KC, McKelvey KS (2008) Hair collection. In: Long RA et al (eds) Noninvasive survey methods for North American carnivores. Island Press, Washington, DC, pp 135-176

Kendall KC, Stetz JB, Roon DA, Waits LP, Boulanger J, Paetkau D (2008) Grizzly bear density in Glacier National Park, Montana. J Wildl Manage 72:1693-1705
Kendall KC, Stetz JB, Boulanger J, Macleod AC, Paetkau D, White GC (2009) Demography and genetic structure of a recovering Grizzly bear population. J Wildl Manage 73:1-17

Long RA, Donovan TM, MacKay P, Zielinski WJ, Buzas JS (2007) Comparing scat detection dogs, cameras, and hair snares for surveying carnivores. J Wildl Manage 71:2018-2025

Long RA, MacKay P, Ray J, Zielinski W (2008) Non invasive survey methods for carnivores. Island Press, Washington, DC

Mertzanis G (1994) Brown bear in Greece: distribution, present status - ecology of a northern Pindus subpopulation. International Conference on Bear Research and Management 9:187-197

Mertzanis Y, Isaak I, Mavridis A, Nikolaou O, Tragos A (2005) Movements, activity patterns and home range of a female brown bear (Ursus Arctos, L.) in the Rodopi Mountain Range, Greece. Belg J Zool 135:217-221

Mertzanis G, Kallimanis AS, Kanellopoulos N, Sgardelis SP, Tragos A, Aravidis I (2008) Brown bear (Ursus arctos L.) habitat use patterns in two regions of northern Pindos, Greece - management implications. J Nat Hist 42:301-315

Murphy MA, Waits LP, Kendall KC (2000) Quantitative evaluation of fecal drying methods for brown bear DNA analysis. Wildl Soc Bull 28:951-957

Murphy MA, Waits LP, Kendall KC (2003) The influence of diet on faecal DNA amplification and sex identification in brown bears (Ursus arctos). Molec Ecol 12:2261-2265

Paetkau D (2003) An empirical exploration of data quality in DNAbased population inventories. Molec Ecol 12:1375-1387

Paetkau D, Calvert W, Stirling I, Strobeck C (1995) Microsatellite analysis of population structure in Canadian polar bears. Molec Ecol 4:347-354

Paetkau D, Shields GF, Strobeck C (1998) Gene flow between insular, coastal and interior populations of brown bears in Alaska. Molec Ecol 7:1283-1292

Piggott MP (2004) Effect of sample age and season of collection on the reliability of microsatellite genotyping of faecal DNA. Wild Res 31:485-493

Rogers LL (1987) Effects of food supply and kinship on social behavior, movements and population growth of black bears in northeastern Minnesota. Wildl Monogr 97:1-72

Roon DA, Waits LP, Kendall KC (2003) A quantitative evaluation of two methods for preserving hair samples. Molec Ecol Notes 3:163-166

Roon DA, Waits LP, Kendall KC (2005) A simulation test of the effectiveness of several methods for error-checking non-invasive genetic data. Anim Conserv 8:203-215

Sadlier LMJ, Webbon CC, Baker PJ, Harris S (2004) Methods of monitoring red foxes Vulpes vulpes and badgers Meles meles: are field signs the answer? Mammal Rev 34:75-98

Schipper J, Chanson JS, Chiozza F, Cox NA, Hoffmann M, Katariya V, Lamoreux J, Rodrigues ASL, Stuart SN, Temple HJ, Baillie J, Boitani L, Lacher TE (2008) The status of the world's land and marine mammals: diversity, threat and knowledge. Science 322:225-230

Schmidt K, Kowalczyk R (2006) Using scent-marking stations to collect hair samples to monitor Eurasian lynx populations. Wildl Soc Bull 34:462-466

Schwartz MK, Luikart G, Waples RS (2006) Genetic monitoring as a promising tool for conservation and management. Trends Ecol Evol 22:25-33

Servheen C, Herrero S, Peyton B (1999) Bears. Status Survey and Conservation Action Plan, Gland, Switzerland and IUCN, Cambridge, UK

Swenson JE, Sandegren F (2000) Conservation of European brown bear populations: experiences from Scandinavia. In: Layna JF et al (eds) La conservacion del oso pardo en Europa: un reto de cara al siglo XXI. Fundación Biodiversida, Madrid, pp 111-116 
Swenson JE, Gerstl N, Dahle B, Zedrosser A (2000) Action plan for the conservation of the brown bear (Ursus arctos) in Europe Nature and environment. Council of Europe, Strasbourg, p 114

Swenson JE, Adamic M, Huber D, Stokke S (2007) Brown bear body mass and growth in northern and southern Europe. Oecologia $153: 37-47$

Taberlet P, Camarra J-J, Griffin S, Uhres E, Hanotte O, Waits LP, DuboisPaganon C, Burke T, Bouvet J (1997) Noninvasive genetic tracking of the endangered Pyrenean brown bear population. Molec Ecol 6:869-876
Vlachos CG, Bakaloudis DE, Dimitriou M, Kritikou K, Chouvardas D (2000) Seasonal food habits of the European brown bear (Ursus arctos) in the Pindos Mountains, Western Greece. Folia Zool 49:19-25

Waits LP, Paetkau D (2005) Noninvasive genetic sampling tools for wildlife biologists: a review of applications and recommendations for accurate data collection. J Wildl Manage 69:14191433

Zedrosser A, Dahle B, Swenson JE, Gerstl N (2001) Status and management of the brown bear in Europe. Ursus 12:9-20 